\title{
希土類金属 $\mathrm{Sm}, \mathrm{Eu}, \mathrm{Gd}$ の高温酸化挙動
}

\author{
荒川 剛* 大野泰子** 塩川二朗*
}

J.Japan Inst.Metals, Vol.51,No.4(1987),pp. 338-341

High Temperature Oxidation Behavior of Rare Earth Metals Sm, Eu and Gd

Tsuyoshi Arakawa*, Yasuko Ohno** and Jiro Shiokawa*

Oxidation of $\mathrm{Sm}, \mathrm{Eu}$ and $\mathrm{Gd}$ was investigated by conventional weight gain tests and SEM with small plates $(1 \mathrm{~mm} \times 1 \mathrm{~mm} \times 0.2 \mathrm{~mm})$ and by the measurement of resistivity of metal thin films in oxygen atmosphere at elevated temperatures. The temperature at which the oxidation of Sm thin film (thickness : $1 \mu \mathrm{m}$ ) began was $780 \mathrm{~K}$ and was close to that for the oxidation of $\mathrm{Sm}$ metal plate. Thin films of Eu and Gd (thickness : $1 \mu \mathrm{m}$ ) oxidized abruptly above about $400 \mathrm{~K}$. However, the oxidation temperatures of the metal plates differed largely from one another. The reaction kinetics for Sm was parabolic and the others obeyed a linear oxidation law. The values of the activation energy of oxidation were compared with those reported in the literature. Further, the state of surface oxide was briefly discussed on the basis of the SEM photographs of cross sections of the oxidized Eu and Gd plates.

(Received August 18, 1986)

Keywords : rare earth metal, samarium, europium, gadolinium, thin film, high temperature oxidation, oxidation kinetics

\section{I. 緒言}

近年, 希土類元素は, 触媒, センサ, 蛍光体, 水素眝蔵 合金，磁石などの機能性材料䍀んに使用されるようになっ てきており，それに関する物性の研究す多い(1)-(4). とて ろで，耐熱合金や鉄鋼に希土類元素を添加すると耐高温酸 化性が向上するということからてれらの希土類金属を含む 合金の高温酸化の研究は多い屯のの ${ }^{(5)-(7)}$, 希土類金属自 身の高温酸化住対する研究は非常に少なく ${ }^{(8)(9)}$ ， その酸化 機構等に対して未知の部分も多い. 著者らはてれまで, 希 土類金属薄膜の酸素に対する反応性を主に薄膜の抵抗変化 の測定の面から検討し，希土類金属薄膜間で酸化温度が大 きく異なることなどを明らかにした (10)(11)。本論文では， $4 f$ 電子が 6 のサマリウム $(\mathrm{Sm})$, 抢よびともに 7 で隣接 する元素であるユーロピウム $(\mathrm{Eu})$, ガトリニウム $(\mathrm{Gd})$ の 高温酸化挙動を比較検討したので報告する.

\section{II. 実験}

市販の希土類金属(純度 : $99.9 \%$, 小塊状)を, 窒素䨌囲 気下,メノウ鉢中で薄く延ばし，乙れをエメリーペーパで
研摩後, 約 $1 \mathrm{~mm} \times 1 \mathrm{~mm} \times 0.2 \mathrm{~mm}$ の形状にそろえ酸化 試験片とした.乙れを数 $10 \mathrm{mg}$ 精秤し熱天秤(理学電機, TG-8085)に装填した後，いずれす乾燥空気中， $0.17 \mathrm{~K}$. $\mathrm{s}^{-1}$ の速度で所定の温度まで昇温し, その後の連続酸化の 増量変化を測定した。な扔，全試料について所定の温度ま で増量変化はほとんど観測されなかった。試験中の温度の 変動幅は土2 K 以内であった。酸化皮膜の形態の観察, 同定は走查電子顕微鏡 $($ 日立 $\mathrm{S}-450$ ) 打よび X 線回折装置 (理学電機 RU-200 V)で行なった。一方, 希土類金属表 面の酸化の様子を調べるために，白金リード線をとりつけ た石英板 $(10 \mathrm{~mm} \times 15 \mathrm{~mm} \times 1 \mathrm{mn})$ を蒸着・抵抗測定が連 続してできるようにしたセル内にセットし，各希土類金属 を室温で真空蒸着 $\left(\right.$ 真空度 $\left.\simeq 1.33 \times 10^{-3} \mathrm{~Pa}\right)$ した。なお， 白金リード線は抵抗測定用リード線に直結し, 蒸着後, 酸 素約 $1.33 \times 10^{4} \mathrm{~Pa}$ を導入し, 温度を $0.07 \mathrm{~K} \cdot \mathrm{s}^{-1}$ の速度で 昇温させながら従来の直流二端子抵抗測定装置 ${ }^{(7)}$ を使って 抵抗変化を追跡した.

\section{III. 結果と考 察}

\section{1. 薄膜の抵抗変化}

Fig. 1 亿, 希土類金属薄膜 (膜厚 : 約 $1 \mu \mathrm{m}$ ) の酸素雾囲

\footnotetext{
* 大阪大学工学部応用化学科(Department of Applied Chemistry, Faculty of Engineering, Osaka University, Suita)

** 大阪大学工学部学生, 現在 : 三菱電機株式会社(Undergraduate Student, Faculty of Engineering, Osaka University, Suita. Present address : Mitsubishi Electric Co Ltd., Amagasaki)
} 


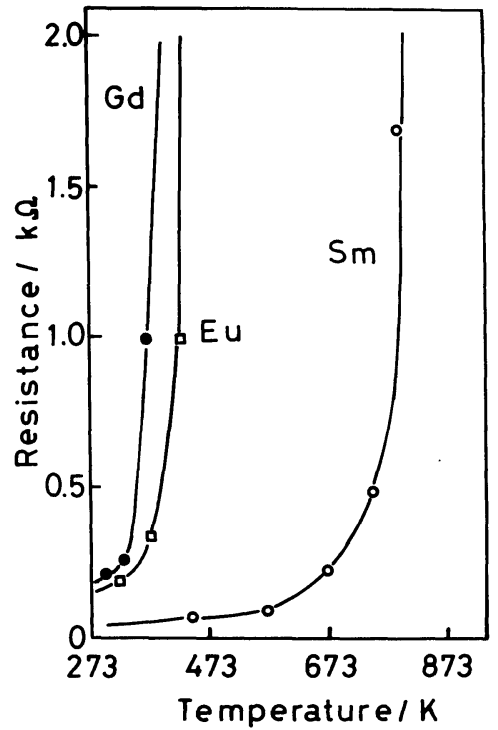

Fig.1 Change in the electrical resistivities of rare earth thin metal films (thickness, $1 \mu \mathrm{m}$; area, $5 \mathrm{~mm} \times 10 \mathrm{~mm}$ ).

気下での抵抗 - 温度曲線を示す. 約 $380 \mathrm{~K}(\mathrm{Gd}), 430 \mathrm{~K}$ $(\mathrm{Eu}), 780 \mathrm{~K}(\mathrm{Sm})$ からそれぞれ急激な抵抗の増加が見ら れる．プラセオジム金属薄膜の場合と異なり ${ }^{(1)(2)}$ ，いずれ の試料むさらに温度を上げれば，絶縁物に近い抵抗值を示 す. $870 \mathrm{~K}$ 付近まで測定後, 室温まで冷やし試料を取り出 すと, 膜表面はいずれむ金属光沢はなくなり, Sm は淡黄 色，他はうすい灰白色を呈していた。また，乙れらの試料 の $\mathrm{X}$ 線回折を行なう之回折角, 強度ともに $\mathrm{C}$ 型 $\mathrm{Ln}_{2} \mathrm{O}_{3}$ $(\mathrm{Ln}=\mathrm{Sm}, \mathrm{Eu}, \mathrm{Gd})$ のあのと一致することがわかった. これから上記の抵抗変化は, 希土類金属薄膜の酸素による 酸化であると判断した.したがって, Sm 金属表面の酸化 はかなり高温でないと抢こらないが， $\mathrm{Eu}, \mathrm{Gd}$ 金属薄膜の 酸化は比較的低温で進行すると言える。

\section{2. 酸化增量曲線}

Fig.2〜Fig.4に Sm, Eu および Gd の酸化増量曲線を 示す. 実験は顕著な酸化増量が認められる温度に設定して 行なった. Sm の場合, 金属薄膜の酸化が急激に認められ る温度之顕著な酸化増量が認められる温度がほぼ一致し， 放物線的な酸化増量曲線が得られた. 酸化が進行し重量増 加がほとんど認められなくなったところで, 酸素と Sm 金属との原子比を求めると $859 \mathrm{~K}$ で $7.2 \mathrm{ks}(2 \mathrm{~h})$ 酸化後の 試料であ約 0.5 であり, $\mathrm{Sm}_{2} \mathrm{O}_{3}$ から予想される值 1.5 よ りはるか化小さ値を示す. 酸化後試料をとり出すと, 金 属光沢はなくなり試料表面は白黄色の酸化物 $\mathrm{Sm}_{2} \mathrm{O}_{3}$ の皮 膜でお打われているが，乙の皮膜をエメリーペーパなどで 研摩し，除去すると金属表面が現れることから，実験条件 下では内部まで酸化が進行しないため上記の結果を与えた あのと判断した． $\mathrm{Eu}$ の場合, 酸化時間を長くすれば, 室

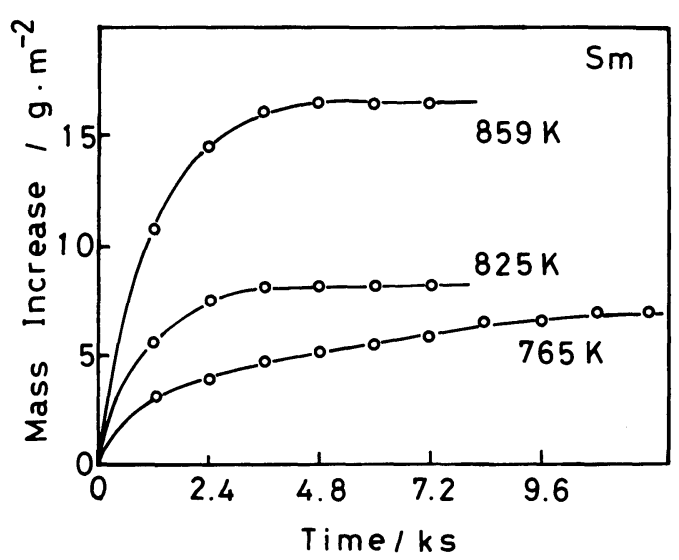

Fig.2 Mass increase during oxidation of $\mathrm{Sm}$ metal at temperatures in the range $765-859 \mathrm{~K}$.

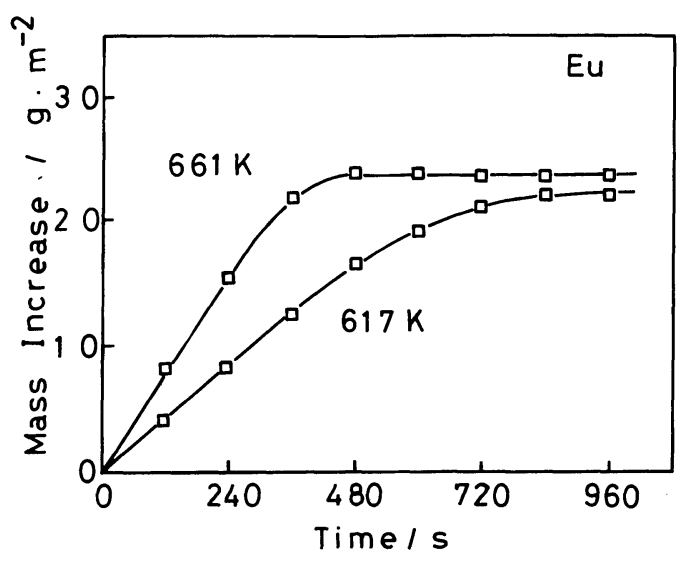

Fig.3 Mass increase during oxidation of $\mathrm{Eu}$ metal at temperatures in the range $617-661 \mathrm{~K}$.

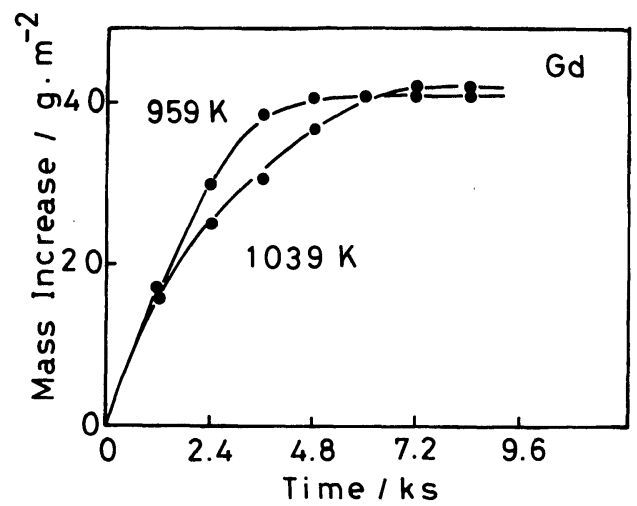

Fig.4 Mass increase during oxidation of $\mathrm{Gd}$ metal at temperatures in the range $959-1039 \mathrm{~K}$.

温 $-470 \mathrm{~K}$ の温度範囲であ十分質量増加が観測されるとと が，Lee 抢よび Greene ${ }^{(9)}$ にり報告されている。本実験 で設定した酸化温度は，Fig.1で得られた結果より約 140 $\mathrm{K}$ ほど高いが，設定温度以上で急激な増加が認められ， 試料全体が $\mathrm{Eu}_{2} \mathrm{O}_{3}$ まで酸化されるのに約 $0.6 \mathrm{ks}(10 \mathrm{~min})$ と非常に短かかった，ところで，Gdの場合には，金属薄 
膜の酸化から予想される温度と大きな差がみられる。本研 究で得られた $\mathrm{Gd}$ 金属片の酸化増量が顕著にみられるのは 約 $960 \mathrm{~K}$ 付近からであり, Basler および Berard ら ${ }^{(12)}$ の 行なった $\mathrm{Gd}$ 金属片の高温酸化の実験で得られた $1000 \mathrm{~K}$ とほぼ同じである。しかし, 前述したように金属薄膜の酸 化の結果から判断すれば，見かけ上重量増加にあらわれな い表面の酸化膜は比較的低温で生成するけれども，乙の酸 化膜を通しての酸化の進行はかなり高温でないとおこらな いむのと考えられる.

$\mathrm{Sm}, \mathrm{Eu}, \mathrm{Gd}$ の酸化増量曲線を対数プロットしたのが, Fig. 5 である. Sm の場合は傾きが $1 / 2$ となり，放物線則 に従う。乙れはVorres および Eyring ら ${ }^{(8)}$ の報告と一致 する．EuとGdの場合はいずれも傾きが 1 となり, 直線 則に従う。Gdの酸化はこれまで放物線則に従うことが報 告されているが(12), 酸化温度がほとんど同じであるにあ かかわらず，我々の結果はこれと一致しない。乙れは $\mathrm{Gd}$ 金属片の作製法协大きく異なるためなのか，現時点では 不明である。しかし，いずれにしても Gd と $\mathrm{Eu}$ では酸化 温度，また後述するように酸化膜の形状が大きく異なるけ れども両者とも直線則に従って酸化が進行するのは, 酸素 の金属面への直接の侵食によって酸化が進行する為と考え られる。

次に各温度における酸化速度定数之, 絶対温度の逆数之 の関係をとると, いずれも良い直線関係が得られ，乙の関 係より各希土類金属の酸化の見かけの活性化エネルギーが 求められる. それらの值を酸化速度定数とともに Table 1 にまとめて示した。なお, Sm の酸化速度定数の単位は, $\mathrm{Sm}$ 金属の酸化が放物線則に従うことから, $\mathrm{g}^{2} \cdot \mathrm{m}^{-4} \cdot \mathrm{s}^{-1}$ である. 直線則に従う $\mathrm{Eu} と \mathrm{Gd}$ を比較すると, $\mathrm{Eu}$ は酸 化温度が低いにあかかわらず酸化速度が大きい. Sm 金属 の酸化の見かけの活性化エネルギー $88 \mathrm{~kJ} \cdot \mathrm{mol}^{-1}$ は, 多 結晶の $\mathrm{Sm}_{2} \mathrm{O}_{3}$ 中の酸素イオンの拡散エネルギー $89 \mathrm{~kJ}$.

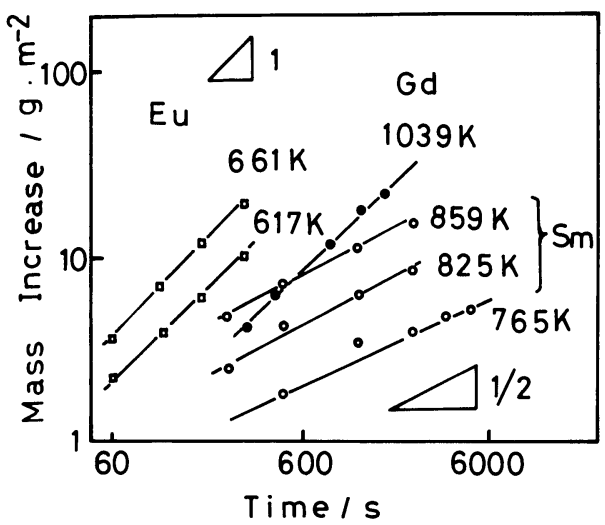

Fig.5 Isothermal mass increase vs. time curves for rare earth metals heated in dry air.

$†$ Basler 执よび Berard ら ${ }^{(12)}$ は, 溶融した Gd を冷 間加工によってフィルム (厚さ: $0.25 \mathrm{~mm}$ )を作り, それをチップ $(3 \mathrm{~mm} \times 3 \mathrm{~mm})$ にして測定している.
Table 1 Characteristics for the oxidation of some rare earth metals.

\begin{tabular}{c|c|c|c}
\hline \hline Sample & Kinetics $^{(a)}$ & Oxidation Rate Constant & $\begin{array}{l}\text { Activation } \\
\text { Energy } \\
\left(\mathrm{kJ} \cdot \mathrm{mol}^{-1}\right)\end{array}$ \\
\hline $\mathrm{Eu}$ & $\mathrm{L}$ & $3.45 \times 10^{-2}(617 \mathrm{~K})^{(\mathrm{b})}$ & 47 \\
$\mathrm{Gd}$ & $\mathrm{L}$ & $1.34 \times 10^{-2}(959 \mathrm{~K})^{(\mathrm{b})}$ & 26 \\
\hline $\mathrm{Sm}$ & $\mathrm{P}$ & $0.62 \times 10^{-2}(765 \mathrm{~K})^{(\mathrm{c})}$ & 88 \\
\hline
\end{tabular}
(a) L : Linear oxidation law, $\mathrm{P}$ : Parabolic oxidation law
(b) Unit: $\mathrm{g} \cdot \mathrm{m}^{-2} \cdot \mathrm{s}^{-1}$, (c) Unit $: \mathrm{g}^{2} \cdot \mathrm{m}^{-4} \cdot \mathrm{s}^{-1}$

$\mathrm{mol}^{-1}$ とほとんど同じである(13). これと, 先述した $\mathrm{Sm}$ 金属の酸化実験の結果から, $\mathrm{Sm}$ 金属の酸化は表面に生成 した酸化皮膜中の酸素イオンの拡散により進行し，酸素イ オンの粒界拡散が律速になっているものと考えられる．ま た，本実験で得られた Gd 金属の酸化の見かけの活性化エ ネルギーは, $1300 \mathrm{~K}$ 以下での多結晶 $\mathrm{Gd}_{2} \mathrm{O}_{3}$ 中の酸素イオ

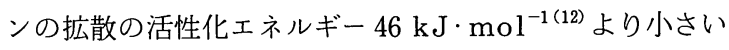
が，乙れは，前述したように著者らの Gd 試料と Basler および Berard ら ${ }^{(12)}$ の Gd 試料の間での酸化様式の違いが 大きく影響しているものと思われる.

\section{3. 酸化皮膜の形態}

試験小片の表面は，かならずしも平滑ではないが，とく に異常酸化を誘起する原因とはならなかった．Fig.6 は， $\mathrm{Eu} 298 \mathrm{~K}$ ，デシケーター中で $7.2 \mathrm{ks}$ ，また Fig.7は $\mathrm{Gd}$ を $975 \mathrm{~K}$ で $0.6 \mathrm{ks}$ 間乾燥空気中で酸化させた後の試 料断面の SEM 写真である. Eu の場合には, 高温では酸 化が非常に早いため, デシケーター中で表面を酸化させた 試料を用いた．乙の酸化後の $\mathrm{Eu}$ の表面は淡白い緑色の粉 末状の皮膜で覆われているが，乙の皮膜は非常に剥離しや すい. 図加らも明らかなように, 表面に粉末状多孔性酸化 物の生成が認められる. 前述したように，ある温度を境に 急激な酸化が進行するのは，乙の多孔性の酸化皮膜が金属 表面全体をおおいつくし，酸素の金属表面への侵食がより 容易になっているのも一因ではないかと考えられる．Gd 金属片を酸化後とり出すと, かなり硬い白色の微少粒が弱 く焼結した塊状になっていた. Fig.7(a)に一部酸化され

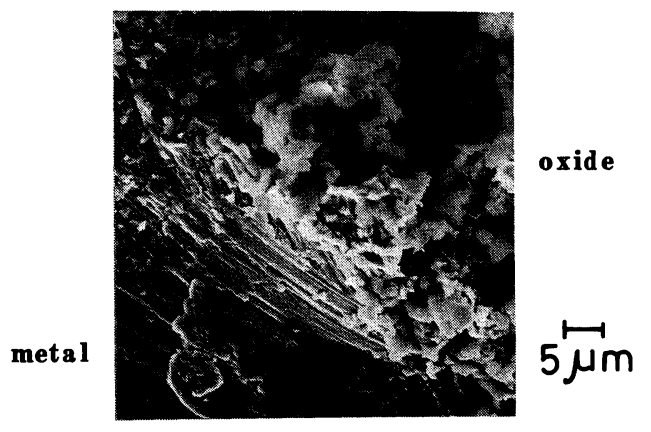

Fig.6 SEM photograph of the cross section of $\mathrm{Eu}$ metal oxidized at $298 \mathrm{~K}$ for $7.2 \mathrm{ks}$. 


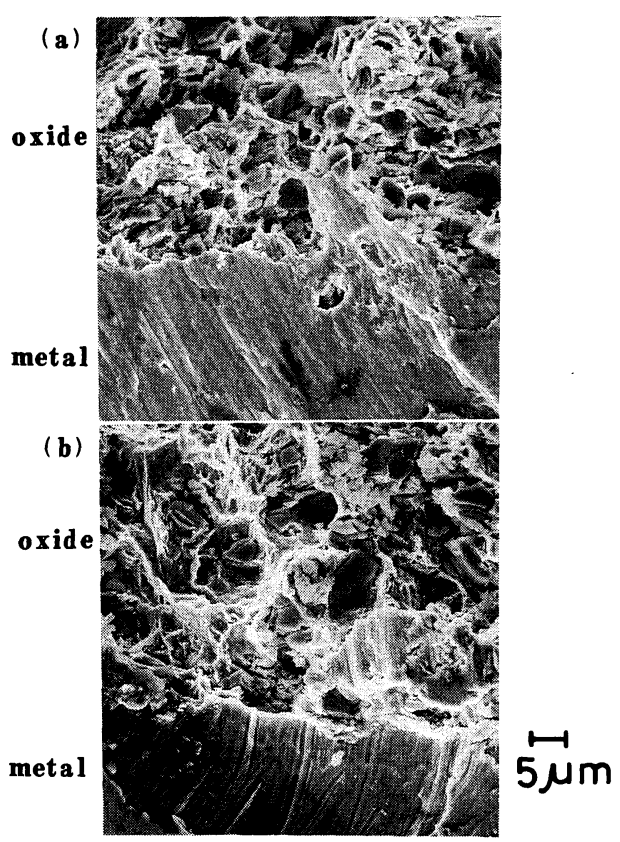

Fig.7 SEM photographs of the cross section of Gd metal oxidized at $975 \mathrm{~K}$ for $600 \mathrm{~s}$.

ずに残る大粒の金属部分と, 無数の微少の酸化した粒子が 焼結したような形で存在している様子を示した。さらに， Fig.7(b)加 , 酸化物界面之金属界面との密着性はかな り良いと判断できる. Gd の場合には酸化温度は高いが, Eu 之同様，急激な酸化が見られ，Fig.7から予想すれば， 高温では無数の割れ面が生じ，乙の割れ面が $\mathrm{Gd}$ 金属片の 酸化の活性化に何らかの役割をはたしているのではないか と考えられる.すなわち，Euと Gd の金属片の酸化は同 じ直線則で進行するが，薄膜の場合と異なり，その酸化温 度に大きな差が出るのは, 表面にできる酸化膜の形態の違 いによるものと推察される.

\section{IV. 結 論}

サマリウム $(\mathrm{Sm})$, ユーロピウム $(\mathrm{Eu})$, ガドリニウム
$(\mathrm{Gd})$ 金属の酸素雾囲気中における高温での酸化を, 重量 増加の測定, SEM, 金属薄膜の抵抗測定により調べ，次 のような基礎的知見を得た。

(1) $\mathrm{Sm}$ 金属薄膜の酸化は $780 \mathrm{~K}$ 付近からはじまるが, これは $\mathrm{Sm}$ 金属片の酸化温度と一致した。また $\mathrm{Eu} と \mathrm{Gd}$ 金属薄膜の酸化は約 $400 \mathrm{~K}$ 以上のほぼ等しい温度で急激 におこるけれどむ, 金属小片の酸化温度は両者で大きく異 なる。

(2) Smの酸化は放物線則に従い, 他のものは直線則に 従って進行する.

(3) Eu と Gd の酸化皮膜の形態を SEM 写真により観 察し, $\mathrm{Eu}$ の酸化皮膜は粉末状かつ多孔性であること, ま た Gdの酸化皮膜はかなり硬い微少粒が弱く焼結した状態 であることを明らかにした。

\section{文献}

(1) R. J. H. Voorhoeve, D. W. Johnson, Jr., J. P. Remeika and P. K. Gallagher : Science, 195 (1977), 827.

( 2 ) T.Arakawa, H.Kurachi and J.Shiokawa : J. Mater. Sci., 20(1985), 1207.

( 3 ) K.H.J.Buschow and H.H.Vanmal : J. LessCommon Met., 29(1972), 203.

(4) G.Blasse, W.L.Wanmaker, J.W.terVrugt and A.Brill : Philips Res. Rep., 23(1969), 189.

( 5 ) K.N.Strafford : High Temp. Technol., 1(1983), 307.

（6）永井 宏, 村井照幸, 三谷裕康: 日本金属学会誌, 42(1978), 1138.

(7) 斎藤安俊: 鉄之鋼, 65(1979), 747 .

(8) K.S.Vorres and L.Eyring : Rare Earth Res., Seminar, Lake Arrowhead, Calif., (1960), 119.

(9) L.Lee and N.D.Greene : Corrosion, 20(1964), 145 t.

(10) T.Arakawa, A.Kabumoto and J.Shiokawa : Thin Solid Films, 120(1984), L69.

(11) T.Arakawa, A.Kabumoto and J.Shiokawa: J. Less-Common Met., 115(1986), 281.

(12) D.B.Basler and M.F.Berard : J.Amer.Ceram. Soc., 57(1974), 447.

(13) L. Eyring : Handbook on the Physics and Chemistry of Rare Earths, vol.3 Ed. by K.A. Gschneidner, Jr. and L.Eyring, North-Halland, Amsterdam, (1979), 378. 